\title{
Density-dependent and independent changes in somatic growth of female North Sea plaice Pleuronectes platessa between 1930 and 1985 as revealed by back-calculation of otoliths
}

\author{
A. D. Rijnsdorp, P. I. van Leeuwen \\ Netherlands Institute for Fisheries Research, PO Box 68, 1970 AB IJmuiden, The Netherlands
}

\begin{abstract}
Changes in the somatic growth of female plaice Pleuronectes platessa L. between 1930 and 1985 is studied by back-calculation of otoliths. It is shown that in the period $1940-49$ growth rate was reduced, which coincided with a 3 -fold increase in the plaice stock due to the closure of the fishery during the second world war. The growth reduction was largest in large fish ( $>45 \mathrm{~cm}$ ) as compared to medium sized fish $(30-40 \mathrm{~cm})$, but could not be detected in the size classes $<20 \mathrm{~cm}$. In large plaice the growth reduction occurred later in time as compared to the medium sized fish. Growth in the immediate pre-and post-war years appeared to be similar. At some time in the 1950 s and 1960 s a growth acceleration started in the size classes up to $30 \mathrm{~cm}$, levelling off in the $1970 \mathrm{~s}$. This growth acceleration was largest in the smallest size classes. Within the period of growth acceleration, the 1963 year class, which was about 3 times the average year class strength, showed a slight but significant reduction in growth. The reduction in growth was restricted to size classes $<30 \mathrm{~cm}$ and was largest in smaller fish. It is concluded that growth rate in plaice is reduced at high density both in the juvenile phase (pre-war period and year class 1963) and in the adult phase (period 1940-49). The increase in growth of juvenile plaice starting in the 1950 s appears to be related to an increase in the availability of food in the coastal waters of the southern North Sea.
\end{abstract}

\section{INTRODUCTION}

Growth rate of fish is a characteristic that may show considerable changes in response to food availability, population density and temperature (Weatherley \& Gill 1987). In addition, growth rate may be under selective pressure by the fishery (Ricker 1981, Nelson \& Soulé 1987). In order to evaluate the influence of each of these factors, long time series of growth data are required which are collected in a consistent way.

North Sea plaice Pleuronectes platessa L. is a suitable candidate for such an analysis, because this wellstudied species has shown substantial changes in growth and remarkable fluctuations in population density due to the reduced fishing during 2 wartime periods. The older literature, reviewed by Wimpenny (1953) and Bannister (1978), suggests densitydependent growth effects, based on smaller length at age of strong year classes and on a reduced length or weight at age during war time periods (Borley 1923, Bückmann 1944, Beverton \& Holt 1957). More recent studies have been unable to provide convincing evidence for density-dependent growth, although a considerable increase in growth rate of small plaice has been observed in the 1960s and 1970s (Bannister 1978). Rijnsdorp \& van Beek (1991) suggested that this increase in growth is related to an increased availability of food.

Long term growth studies have a number of inherent difficulties. Firstly, it is always questionable whether age determinations carried out over a long time period by different people have been consistent. In plaice, age determinations have traditionally been carried out using untreated otoliths. This methodology is suitable for ageing the younger, fast growing fish up to about $8 \mathrm{yr}$ old, but may seriously underestimate the age of older, slow growing plaice (Heincke 1908, van Leeuwen \& Groeneveld 1988). In addition, a different assump- 
tion about the date of birth as the reference to age determinations have been made in the past (1 January, 1 April or variable depending on the appearance of a new growth zone; compare Wallace 1907, 1914). A study of growth in plaice is further complicated because the size- and age-groups are distributed differently (Heincke's law; Wimpenny 1953). Small plaice are concentrated in the shallow coastal and estuarine nursery grounds from where they disperse over the deeper off-shore grounds. Since this dispersion is sizeand age-dependent (Beverton \& Holt 1957, Rijnsdorp 1989), it is necessary to take account of the differences in spatial distribution of slow and fast growing fish. This problem can be circumvented for adult fish if sampling is restricted to the spawning period, when the mature plaice gather on the spawning grounds (de Veen 1964).

One possible way to overcome sampling and age reading problems is to reconstruct the changes in growth from the pattern of otolith growth employing a back-calculation technique (Southward 1962). The back-calculation technique has been validated for plaice using tagging experiments in combination with tetracycline labeling of otoliths (Rijnsdorp et al. 1990). This paper presents the results of a back-calculation study of female North Sea plaice using otoliths collected between 1948 and 1985. The older fish included in these samples allowed us to look back as far as the late 1920s. We will focus on changes in growth during the period of the second world war (1940-45) as compared to that in the immediate preand post-war years, and to the growth acceleration in the 1.960 s and 1970 s. Special attention is further given to the question of which size classes of plaice have been particularly affected. The observed changes will be discussed in relation to trends in population abundance.

\section{MATERIAL AND METHODS}

Otolith samples. The somatic growth of female plaice in the period $1930-85$ was studied by backcalculation of growth patterns in otoliths. Otolith samples collected in the southern North Sea, roughly between 52 and $54^{\circ} \mathrm{N}$ and 1 and $4^{\circ} \mathrm{E}$, and in the spawning period between January and March were considered, except for a few otoliths collected in summer 1955 . The study was constrained by the availability of otolith samples, since prior to 1958 - when intensive sampling started in, among other countries, The Netherlands - only limited numbers were available. From the period 1948-55 two sets of otolith samples (otolith sets 2 and 3 ) were made available by the Fisheries Laboratory Lowestoft (courtesy of
Drs R. S. Millner and J. D. Riley). These otolith sets represent a length stratified random selection of plaice $>25 \mathrm{~cm}$ of age 4 to 15 , with a few older females up to age 28. In the period 1958-85 otoliths were selected from Dutch market samples belonging to individual year classes sampled at age $4,5,6,8,10$ to 16 (otolith sets 4 to 7 ) or from a range of fish sizes in individual years (otolith sets 8 to 10). Although not sampled at the appropriate time and place, additional otoliths collected during summer on coastal grounds just north of Terschelling in 1932 and 1933 (otolith set 1) were analysed to compare estimates of juvenile growth rate from otolith of old fish and of young fish. In total 1421 otoliths of individual females between ages 2 and 28 were studied. A summary of the age composition of the available otolith sets is given in Table 1. A map of the North Sea with the topographical names used is shown in Fig. 1.

Back-calculation method. Preparation of otoliths and back-calculation procedure followed Rijnsdorp et al. (1990), of which a short summary follows. One otolith per fish was cut along the lateral plane through the nucleus, polished and burned on a brass plate above a Bunsen gas flame to clarify the pattern of white and dark bands. The burned otoliths were mounted in plasticine and read with a binocular microscope under reflected light. The outer tips of the hyaline bands were drawn on paper using a drawing mirror at a magnification of $24 \times$ and the maximum diameter of each annulus was measured from the drawing with a ruler in units of $0.5 \mathrm{~mm}$. The measurements were all taken using the main axis of growth of the otolith. The length at the time of annulus formation $L$, was calculated according to

$$
L_{i} / L_{t}=\alpha\left(O_{i} / O_{t}\right)^{\beta}
$$

where $L_{t}=$ length at capture; $O_{i}=$ otolith diameter of the ith annulus in the otolith; $O_{t}=$ diameter of the total otolith $_{i} \alpha=$ proportionality coefficient; and $\beta=$ backcalculation coefficient estimated from the relationship between fish length and otolith width $(\beta=1.364)$. Rijnsdorp et al. (1990) presented evidence for the validity and accuracy of the back-calculation method and further showed that the time of annulus formation corresponds to 1 April.

Since it was our purpose to reconstruct growth rate of plaice as far back in time as possible, we have used otoliths of very old females, which need special treatment. Fig. 2 shows a drawing of a transversal section of a burned otolith of a 23 yr old female plaice. The pattern of light and dark zones can be recognized easily in the central parts of the otolith, but at the periphery the annuli become densely packed. The age can be estimated most easily by 
Table 1. Pleuronectes platessa. Summary of the available otolith samples used. Sampling type indicates whether the otoliths were sampled from a size-range of plaice $(\mathrm{S})$ or from a particular year-class ( $\mathrm{Y}$ )

\begin{tabular}{|c|c|c|c|c|c|c|c|c|c|c|}
\hline $\begin{array}{r}\text { Otolith set: } \\
\text { Type: } \\
\text { Year/Year class: }\end{array}$ & $\begin{array}{c}1 \\
\text { S } \\
1932-33\end{array}$ & $\begin{array}{c}2 \\
\mathrm{~S} \\
1948-51\end{array}$ & $\begin{array}{c}3 \\
S \\
1955\end{array}$ & $\begin{array}{c}4 \\
Y \\
1955-61\end{array}$ & $\begin{array}{c}5 \\
Y \\
1963\end{array}$ & $\begin{array}{c}6 \\
Y \\
1969\end{array}$ & $\begin{array}{c}7 \\
Y \\
1972-74\end{array}$ & $\begin{array}{c}8 \\
\mathrm{~S} \\
1982-85\end{array}$ & $\begin{array}{c}9 \\
S \\
1960\end{array}$ & $\begin{array}{c}10 \\
S \\
1974\end{array}$ \\
\hline \multicolumn{11}{|l|}{ Age } \\
\hline 2 & 1 & 0 & 0 & 0 & 0 & 0 & 0 & 0 & 0 & 0 \\
\hline 3 & 10 & 0 & 0 & 2 & 0 & 0 & 4 & 8 & 0 & 12 \\
\hline 4 & 5 & 1 & 2 & 51 & 39 & 40 & 50 & 35 & 6 & 6 \\
\hline 5 & 32 & 4 & 2 & 23 & 43 & 43 & 50 & 28 & 7 & 7 \\
\hline 6 & 17 & 8 & 4 & 35 & 33 & 41 & 47 & 28 & 10 & 9 \\
\hline 7 & 8 & 3 & 5 & 48 & 0 & 0 & 9 & 22 & 11 & 3 \\
\hline 8 & 6 & 0 & 6 & 43 & 36 & 39 & 15 & 9 & 9 & 5 \\
\hline 9 & 6 & 5 & 0 & 41 & 0 & 0 & 20 & 9 & 2 & 1 \\
\hline 10 & 5 & 4 & 1 & 26 & 33 & 28 & 14 & 8 & 7 & 2 \\
\hline $11-15$ & 6 & 13 & 6 & 23 & 0 & 0 & 6 & 5 & 24 & 24 \\
\hline $16-20$ & 2 & 22 & 0 & 0 & 18 & 0 & 0 & 0 & 5 & 15 \\
\hline $20-30$ & 0 & 7 & 3 & 0 & 0 & 0 & 0 & 0 & 5 & 5 \\
\hline Total & 98 & 67 & 29 & 292 & 202 & 191 & 215 & 152 & 86 & 89 \\
\hline
\end{tabular}

counting the annuli from the centre to the arrow B. Drawing the outer tips of the annuli, projected on the major growth axis A-A, however, becomes difficult in the peripheral zone. The dense packing of annuli along the major axis is due to a change in the direction of growth of the otolith, which occurred around age 10. Up to this age, the annuli were laid down in the posterior-anterior direction, whereas beyond this age the direction of growth shifted more and more to

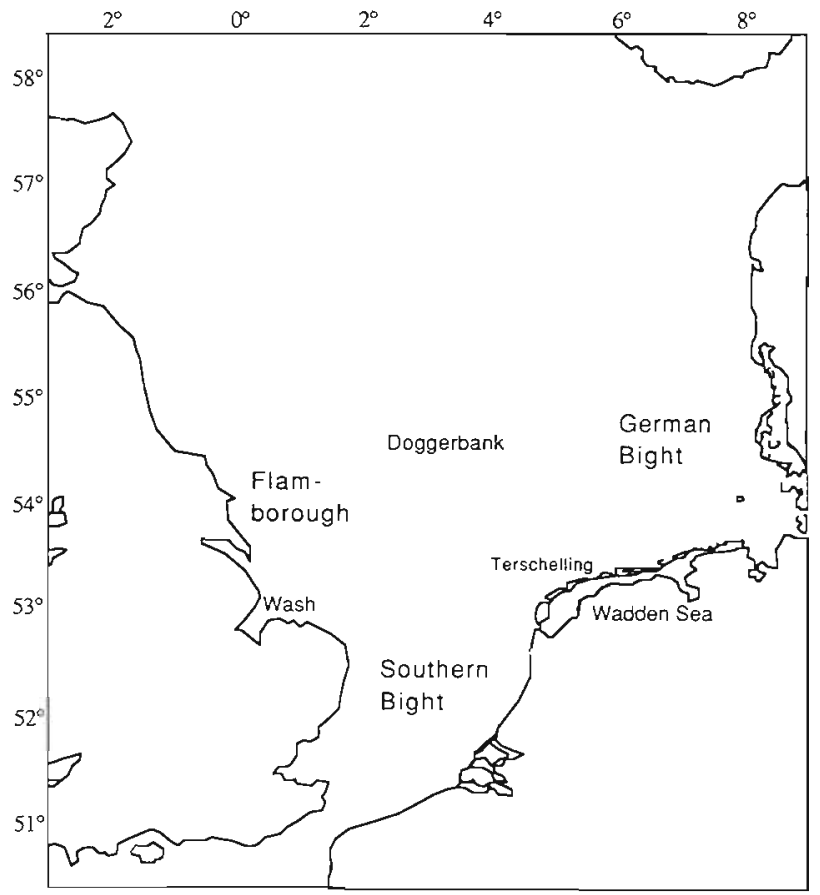

Fig. 1. North Sea with the topographical names used in this study the dorso-ventral axis. This change in the axis of growth occurs gradually. When the packing of annuli along the major growth axis became so dense that the individual annuli could no longer be distinguished, the diameter was interpolated between the ultimate otolith size and the size of the last annuli which could be effectively distinguished. This is indicated by the dashed lines in Fig. 2. Interpolation of otolith measurements implies that within the year range that corresponds to the interpolated annuli, no differences in growth could be distinguished between individual years. Interpolation occurred in about $30 \%$ of the females beyond age 12 or size $>45 \mathrm{~cm}$.

The back-calculation method assumes that the curvilinear relationship between otolith width and body size as estimated for the population also applies to individual females, or in other words that the backcalculation coefficient $\beta$ in Eq. 1 applies to individual females. It is likely, however, that individual females will differ in the body size at which the change in direction of growth of the otolith starts, as well as in the extent to which this occurs. Deviations of the individual back-calculation coefficient from the population estimate will introduce a bias in the estimated growth curve of that individual. If $\beta_{\text {individual }}>\beta_{\text {population the }}$ growth at early ages will be overestimated and the growth at older ages will be underestimated. Since the otolith width - body size relationship was determined over a range of body sizes from 8 to $60 \mathrm{~cm}$, only otoliths of fish $<60 \mathrm{~cm}$ were included in the analysis. Although individual growth curves may be biased to some degree, the average growth estimates should be unbiased 


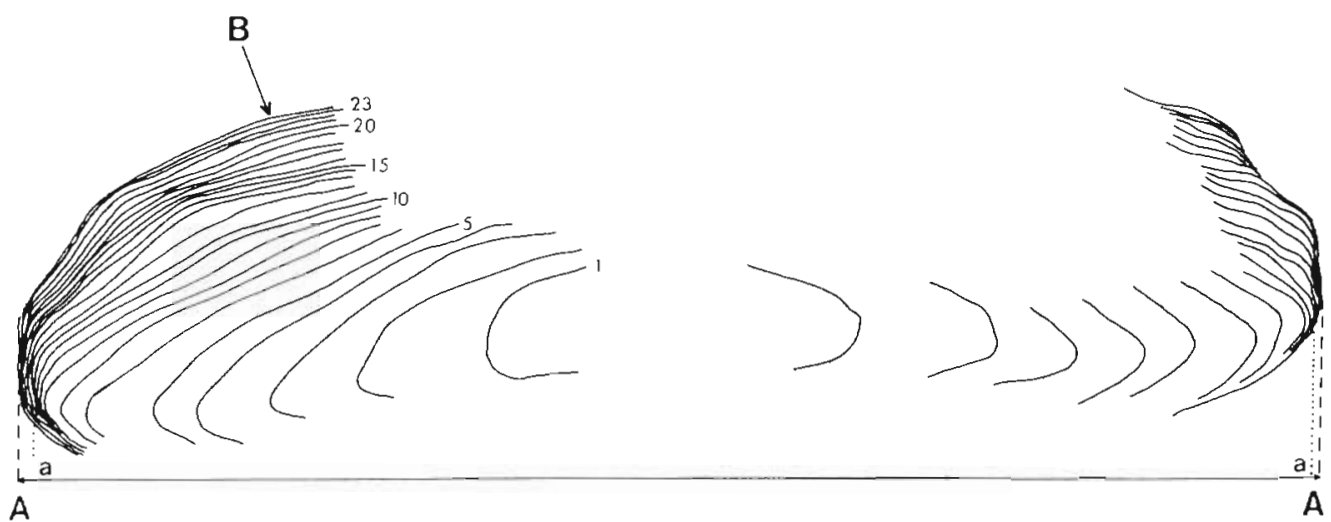

Fig. 2. Pleuronectes platessa. Drawing of a transversal section of an otolith of a female plaice caught on $18 \mathrm{June} 1955$ (no. 18 , set 3). The age was estimated at $23 \mathrm{yr}$. Otolith measurements for back-calculation were made along the main axis of growth $\mathrm{A}-\mathrm{A}$. Age determination employed the axis in direction B, which facilitated the determination of the annuli. Around age 10 the direction of otolith growth gradually changed and new growth zones were increasingly laid in the ventral-dorsal direction. The zone between the dashed (A) and the dotted lines (a) shows where otolith measurements were interpolated because annuli could no longer be recognised individually along the main axis of growth $\mathrm{A}-\mathrm{A}$

\section{RESULTS}

The average back-calculated lengths for females born in various periods since 1925, omitting females sampled at an age < 6 yr (see below), show that the present growth rate (year classes 1970-79) is substantially higher $(t$-test, $p<0.05)$ than in year classes born before 1950 (Fig. 3). The length of the year classes born in 1935-39 is higher than those born in 1940-49 up to age 6 but then becomes smaller, the difference being significant for ages 2 to 5 ( $t$-test, $p<0.05$ ). The length of plaice born during the war $(1940-44)$ is smaller than any other group of year

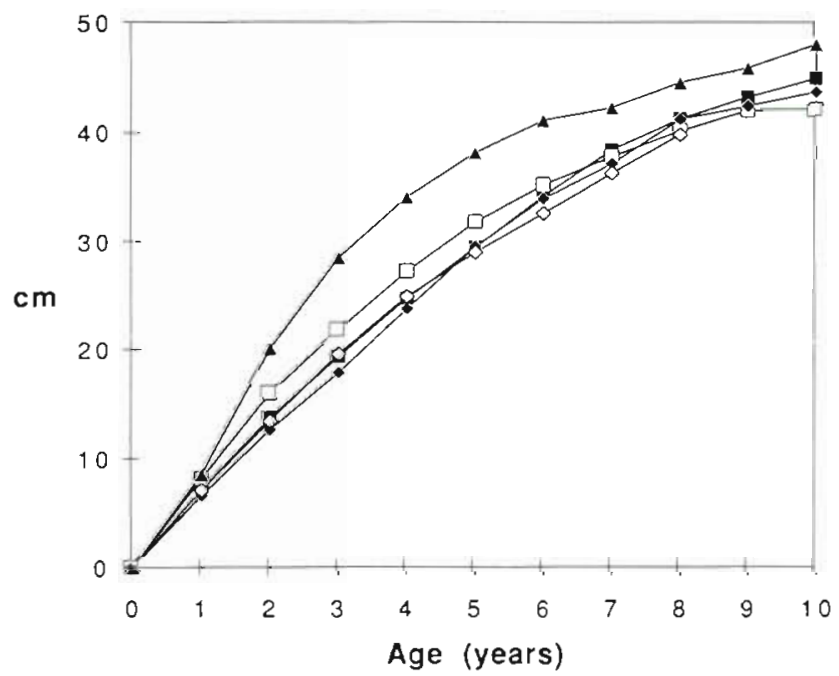

Fig. 3. Pleuronectes platessa. Average back-calculated length at ages 1 to 10 of year classes born in various time periods since 1925. (ロ) before 1935; ( $\square$ ) 1935-39; (•) $1940-44 ;(\diamond) 1945-49 ;$ (ム) $1970-79$ classes for ages 2 to 4 , but varies around a similar value for older age groups. The difference is significant with year class 1970-79 and 1935-39 $(p<0.05)$ and almost significant with year classes 1945-49 ( $t$-test, $0.05<p<0.10)$. It is difficult to interpret the changes in the average cumulative length shown in Fig. 3 in terms of changes in the rate of growth in certain periods. Because the annual length increment decreases with fish size, the analysis of the changes in growth should take account of the size of the fish. We therefore estimated the length increments for $5 \mathrm{~cm}$ size classes in various time periods of 5 years. The time period between 1940 and 1949 was divided into five 2 yr periods, because if there is an effect of density due to lack of exploitation, then this effect will gradually build up and shorter time periods might show the development in the density-dependent effect more clearly.

The annual length increments, estimated from the pooled data of otolith sets 2 to 10 , are shown in Fig. $4 \mathrm{~A}$ to $\mathrm{H}$ together with the approximate $95 \%$ confidence limits. Since an individual female may provide several estimates of length increment in a particular size-class or time-period, the mean length increment was calculated for each female before calculating the population average. The number of observations in the legend thus refers to the number of individual females in a particular cell. In general, the confidence limits are much wider in the earlier periods due to lower sampling levels.

The growth estimates of size class $10-15 \mathrm{~cm}$ indicate an almost 2-fold increase after 1950 compared to the 1930 s. The growth acceleration is also shown by larger size-classes up to $25-30 \mathrm{~cm}$, but is absent in the larger ones. A growth reduction during the war is only appar- 
A. size class $10-15 \mathrm{~cm}$

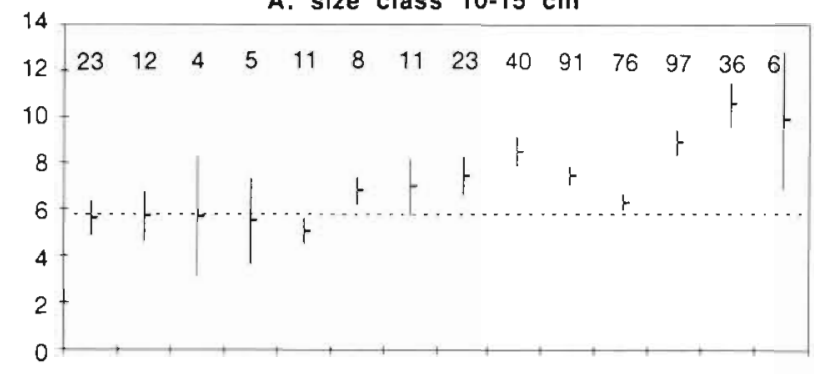

B. size class $15-20 \mathrm{~cm}$

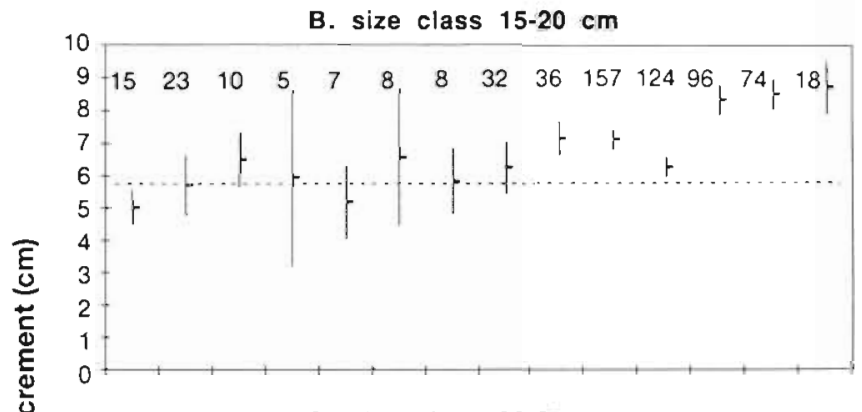

C. size class $20-25 \mathrm{~cm}$

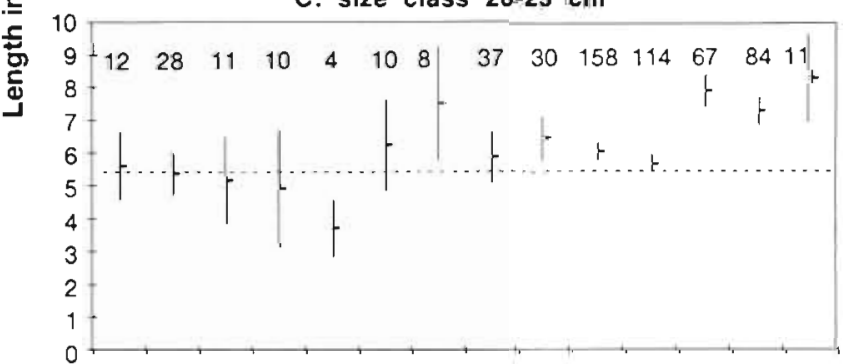

D. size class $25-30 \mathrm{~cm}$

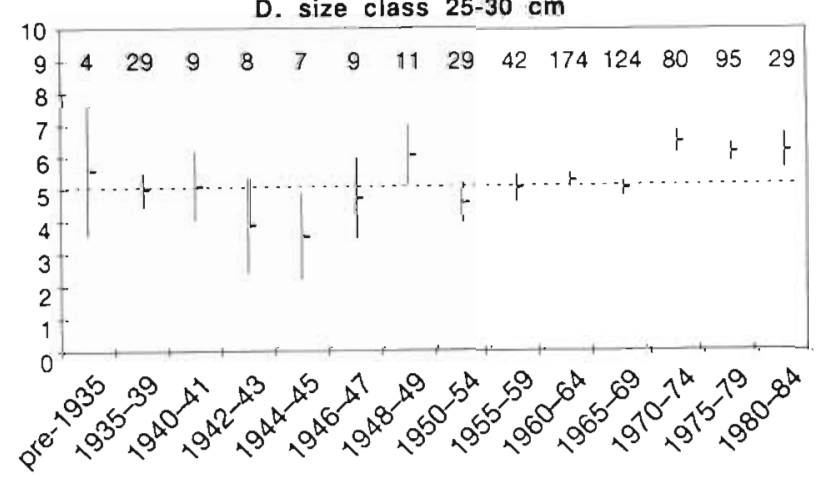

E. size class $30-35 \mathrm{~cm}$

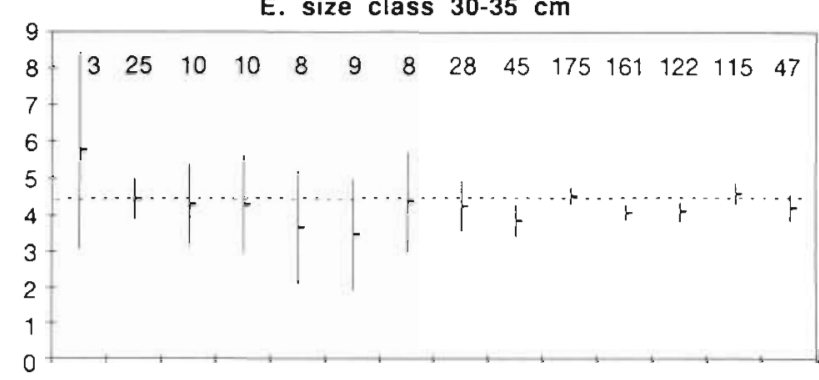

F. size class $35-40 \mathrm{~cm}$

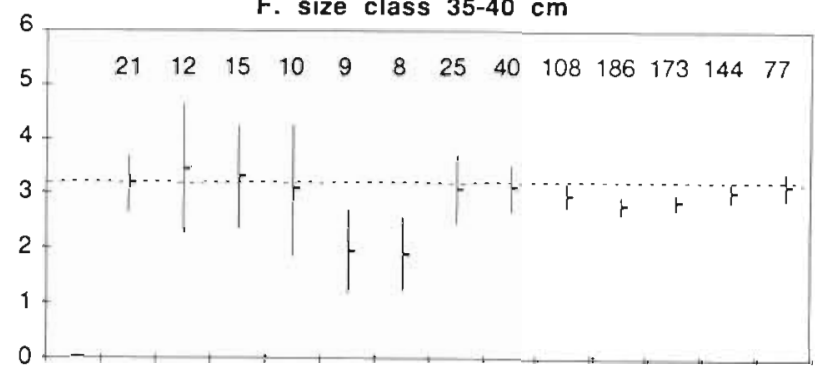

G. size class $40-45 \mathrm{~cm}$

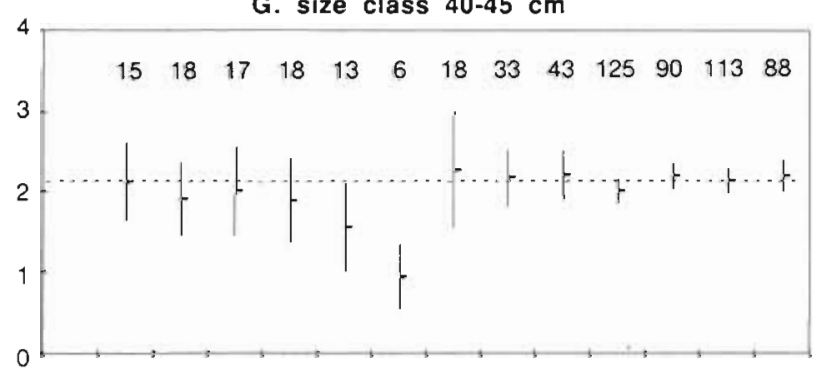

H. size class $45-50 \mathrm{~cm}$

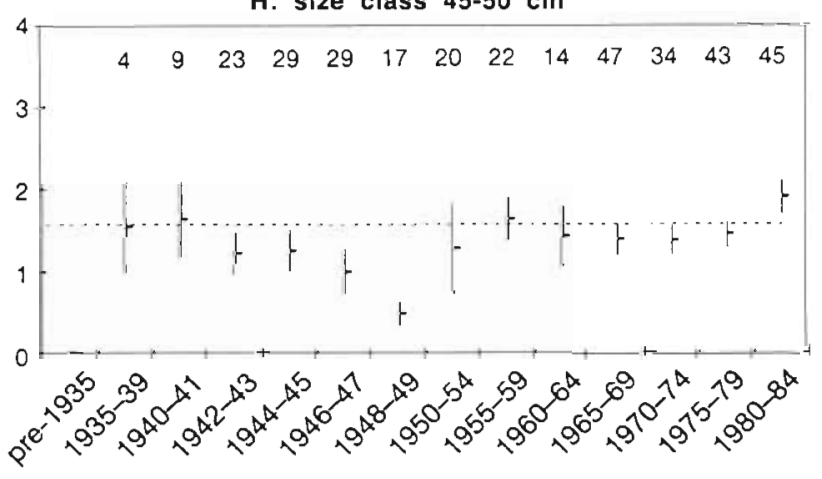

Fig. 4. Pleuronectes platessa. Back-calculated annual length increments in the period 1930-84 for different size classes of female plaice. Vertical bars indicate $2 \mathrm{SE}$. Dashed line shows the pre-war length increment. Numbers along top indicate number of observations

ent in the size-classes $20-25 \mathrm{~cm}$ and larger. The magnitude of the growth reduction appears to increase with size, and the timing shifts from actual war-time period (1940-45) in size classes $20-30 \mathrm{~cm}$ to the immediate post-war years in the larger plaice (Fig. 5). Finally, the present growth rate of size classes $\geq 30 \mathrm{~cm}$ is markedly similar to the one in the pre-war period.

The back-calculated growth rates for the pre-war period based on otolith samples collected on the spawning grounds in 1948-51 showed a close agreement with the growth rate back-calculated from the 1932-33 samples collected on the nursery grounds in size classes < 10 and $10-15 \mathrm{~cm}$ (Table 2). However, for the size classes 15-19 and 20-25 cm the estimates from the nursery samples were slightly lower. From the 1932-33 samples only ages 2 to 6 were selected because these are typically representative for the coastal grounds. The growth rate of the females 


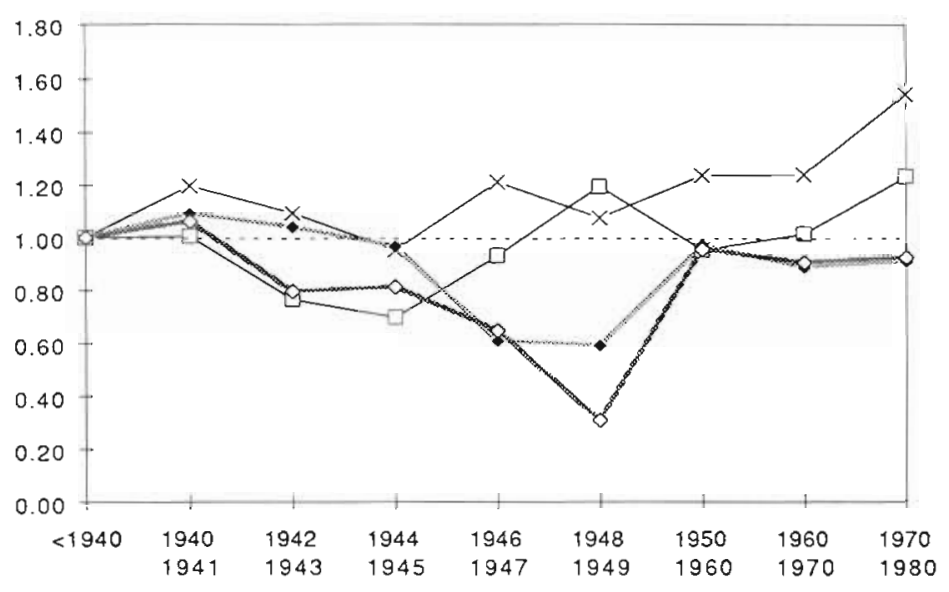

Fig. 5. Pleuronectes platessa. Growth rates, standardized to the growth rate in the pre-war period, of selected size classes illustrating the difference in the timing and the level of the reduction in growth in the period 1940-49. (x) 15-20 cm; (ㅁ) $25-30 \mathrm{~cm}_{i}(\bullet) 35-40 \mathrm{~cm}_{\text {i }}$ (๖) $45-50 \mathrm{~cm}$

between 6 and 12 years old was somewhat lower, about 0.6 to $1.3 \mathrm{~cm}$ less than the females of ages 2 to 6 of size class up to $24.9 \mathrm{~cm}$. For size classes between 25 and $35 \mathrm{~cm}$ the average annual growth was $2.7 \mathrm{~cm}$. However, these older females are considered to be not representative since they have been sampled on the shallow nursery grounds and not in the deeper offshore waters.

Fig. 4 shows that in the period 1965-69 a dip in growth rate occurs in the 3 smallest size classes, which is related to the 1963 year class. This year class was about 3 times the average size and strongly dominated the data set for this period. In order to analyse whether this year class differed in growth rate, its growth is compared to that of year classes born in 1955-60 (otolith set 4) and 1969-74 (pooled data sets 6 and 7). Fig. 6 clearly shows that the annual length increment of the 1963 year class was reduced in the size classes up to $30 \mathrm{~cm}$. Compared to the 1955-60 year classes the largest reduction in growth occurred in the smallest size classes. The data for the 1969-74 year classes again illustrate the increase in the growth during the 1970s.

The length at the end of the first year (L1) and the approximate $95 \%$ confidence limits for year classes born between 1930 and 1980 is plotted in Fig. 7. For the year classes born in the late $1920 \mathrm{~s}$ two estimates are available: those based on otolith samples collected since 1948 on the spawning ground; and those based on otolith samples collected in 1932 and 1933 on the nursery grounds north of Terschelling (Table 2). The results of both samples were close. The number of observations varies substantially between individual year classes and the results can therefore be used only to inspect changes in overall level between periods. The L1 of year classes 1930-50 varies around $7 \mathrm{~cm}$, with slightly higher values for year classes 1936-39. Year classes born between 1950 and 1980 vary around 8 to $9 \mathrm{~cm}$. The higher value of the L1 since the $1950 \mathrm{~s}$ corresponds to the higher growth rate of $10-15 \mathrm{~cm}$ plaice observed in this period (Fig. 4A). The L1 of the 1940-44 year classes is slightly lower than the average pre-war level.

\section{DISCUSSION}

\section{Methodology}

A number of factors may bias growth estimates obtained by back-calculation of otoliths: incorrect backcalculation procedure, sampling bias, size-selective mortality (Casselman 1987, Francis 1990). The back-

Table 2. Pleuronectes platessa. Back-calculated length increments in the period 1920-39 from otoliths of 2 to 6 yr old female plaice collected in June on the nursery grounds north of Terschelling (set 1); and otoliths of adult females collected on the spawning grounds in the Southern Bight in 1948-51 (set 2)

\begin{tabular}{|c|c|c|c|c|c|c|}
\hline \multirow[b]{2}{*}{$\begin{array}{l}\text { Size-class } \\
(\mathrm{cm})\end{array}$} & \multicolumn{3}{|c|}{ Set 1 samples 1932-33 } & \multicolumn{3}{|c|}{ Set 2 samples $1948-51$} \\
\hline & $\begin{array}{c}\text { Growth } \\
(\mathrm{cm})\end{array}$ & $\begin{array}{l}\mathrm{SD} \\
(\mathrm{cm})\end{array}$ & $\mathrm{n}$ & $\begin{array}{l}\text { Growth } \\
(\mathrm{cm})\end{array}$ & $\begin{array}{l}\mathrm{SD} \\
(\mathrm{cm})\end{array}$ & $n$ \\
\hline$<10$ & 6.3 & 1.5 & 59 & 6.8 & 1.8 & 44 \\
\hline $10-14$ & 5.7 & 1.4 & 47 & 5.7 & 1.9 & 26 \\
\hline $15-19$ & 4.8 & 0.8 & 38 & 5.2 & 1.5 & 30 \\
\hline $20-24$ & 4.5 & 1.2 & 20 & 5.6 & 1.8 & 33 \\
\hline $25-29$ & - & - & - & 5.0 & 1.5 & 32 \\
\hline $30-34$ & - & - & - & 4.8 & 1.9 & 28 \\
\hline $35-39$ & - & - & - & 3.2 & 1.4 & 24 \\
\hline $40-44$ & - & - & - & 2.6 & 1.8 & 18 \\
\hline $45-50$ & - & - & - & 1.3 & 0.5 & 5 \\
\hline$>50$ & - & - & - & 1.9 & - & 1 \\
\hline
\end{tabular}




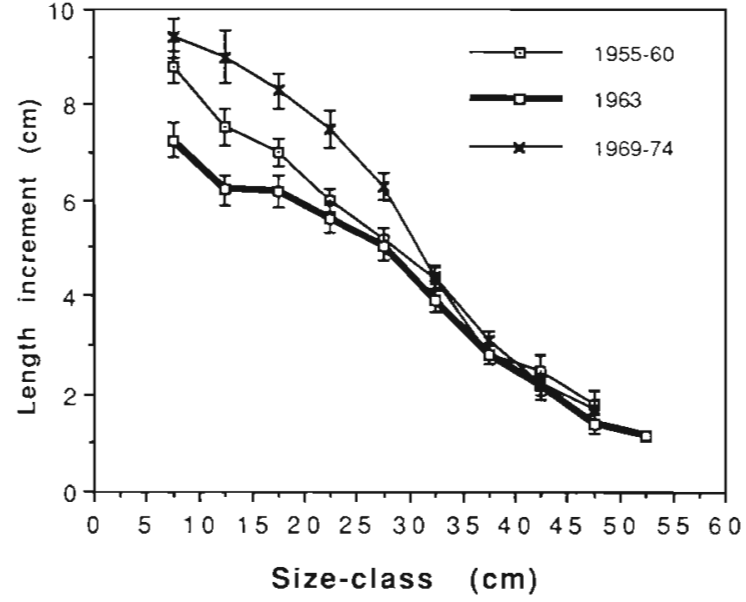

Fig. 6. Pleuronectes platessa. Back-calculated annual length increments in relation to body size for year class born in 1963, which was about 3 times the average size, compared to those born earlier (1955-60) and later (1969-74). Vertical bars indicate $2 \mathrm{SE}$

calculation procedure applied here has been verified by tagging experiments in which otoliths were labelled with tetracycline at tagging (Rijnsdorp et al. 1990). Strictly, this validation only applies to growth estimates of medium sized fish, because no large plaice were included in the experiment. Therefore, back-calculated growth rates of large plaice $(>40 \mathrm{~cm}$ ) have been compared with estimates obtained from tagging experiments. In Table 3 the growth rate of female plaice tagged with Peterson discs and recaptured after 11 to 13 mo in the 1970 s is compared with growth rates estimated by back-calculation. Growth rate of tagged fish was corrected for shrinking according to Rijnsdorp et al. (1990). The correspondence between the 2 data

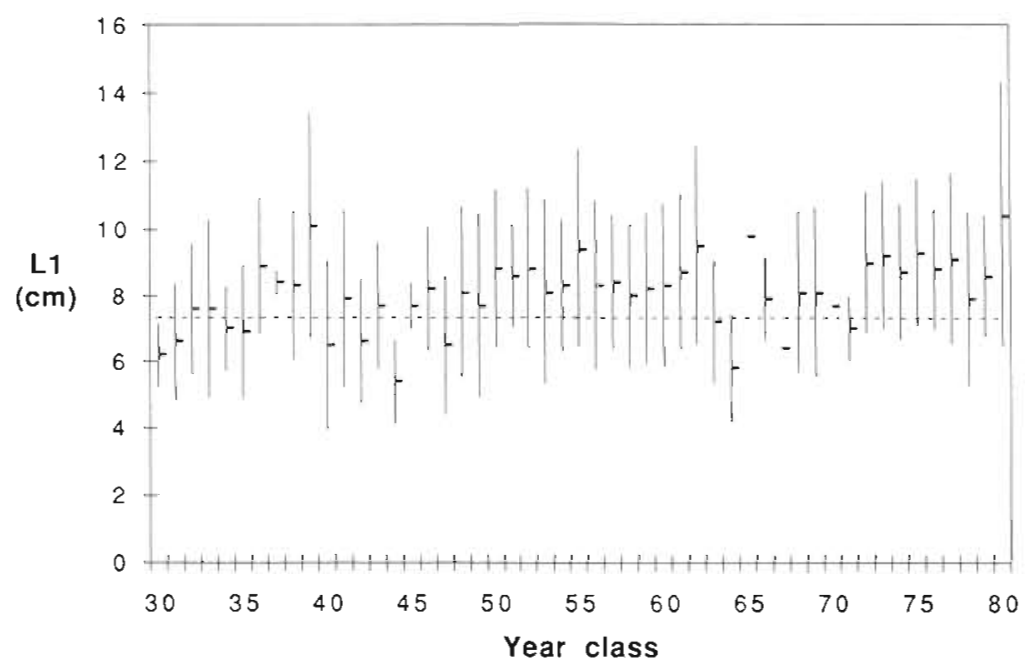

Fig. 7. Pleuronectes platessa. Variations in the back-calculated length at the end of the first year $(\mathrm{L} 1, \mathrm{~cm})$ for the year classes born between 1930 and 1980 sets is rather good, although the number of observations in the larger size groups is small. Back-calculated growth in older fish may be underestimated because underestimation of age is likely to occur in large fish that grow very slowly. In the otoliths of these fish the annuli become densely packed at the outer edge and are sometimes difficult to count. This problem does not occur in younger fish which still show a reasonable somatic growth. An indication for such bias might be that the number of females assigned to the outstanding year class 1928, was smaller than to the rather poor year classes 1930 and 1931 (Bannister 1978).

Sampling bias may lead to overestimation of the back-calculated length of younger age-groups if the otolith samples are taken from market samples which include partially recruited age-groups. Fig. 8 shows the relationship between growth increment and body size estimated from samples taken at selected ages for the 2 largest data sets ( 5 and 6 ) of individual year classes (1963 and 1969). In both data sets the estimated growth rate is highest when the females are sampled at a young age: age 4,5 and 6 in year class 1963, and age 4 in year class 1969. Inspection of the back-calculated size distributions of these year classes revealed that at these younger ages part of the cohort was indeed below the minimum landing size. In order to reduce this source of bias, only females of age 6 and older have been included in the present analysis.

A further bias may be caused by size-selective mortality (Ricker 1969). This type of mortality due to either natural causes or to fishing may be directly or indirectly related to growth rate. Although very little is known about growth related mortality in natural populations, we may speculate that slower growing fish suffer from a higher predation mortality, because of their smaller size. On the other hand, fast growing plaice may be expected to experience a higher mortality due to fishing, since they will leave the shallow coastal nursery areas and enter the main fishing grounds at a younger age than slow growing fish. Given the high level of fishing mortality of $40 \%$ per year as compared to the level of natural mortality $(10 \%$ per year; Beverton 1964), size-selective fishing mortality will probably dominate over other type of size-selective mortality, leading to a proportional increase of slow growing fish among the survivors up to the age of full recruitment. This type of bias may also have contributed to the higher growth estimates obtained from otolith samples of young females in Fig. 8. 
Table 3. Pleuronectes platessa. Comparison of annual length increments of female plaice as obtained by tagging experiments and back-calculation of otoliths. The tagging data refer to the southern North Sea in the period 1970-80 (Rijnsdorp et al. 1990). The back-calculations refer to the pooled data of otolith sets 6 and 7 (year classes 1969-74)

\begin{tabular}{|c|c|c|c|c|c|c|}
\hline \multirow[b]{2}{*}{$\begin{array}{l}\text { Size-class } \\
(\mathrm{cm})\end{array}$} & \multicolumn{3}{|c|}{ Tagging data } & \multicolumn{3}{|c|}{ Back-calculation } \\
\hline & $\begin{array}{c}\text { Growth } \\
\text { increment }(\mathrm{cm})\end{array}$ & $\begin{array}{l}\mathrm{SD} \\
(\mathrm{cm})\end{array}$ & $\mathrm{n}$ & $\begin{array}{c}\text { Growth } \\
\text { increment }(\mathrm{cm})\end{array}$ & $\begin{array}{l}\mathrm{SD} \\
(\mathrm{cm})\end{array}$ & $\mathrm{n}$ \\
\hline$<10$ & - & - & - & 9.4 & 2.6 & 145 \\
\hline $10-14$ & - & - & - & 9.0 & 2.8 & 98 \\
\hline $15-19$ &.- & - & - & 8.3 & 2.1 & 130 \\
\hline $20-24$ & 7.3 & 2.4 & 124 & 7.5 & 2.0 & 112 \\
\hline $25-29$ & 5.9 & 2.0 & 9 & 6.3 & 1.6 & 125 \\
\hline $30-34$ & 4.4 & 2.1 & 26 & 4.4 & 1.5 & 149 \\
\hline $35-39$ & 2.8 & 1.4 & 40 & 3.1 & 1.1 & 143 \\
\hline $40-44$ & 1.9 & 1.0 & 31 & 2.2 & 0.8 & 65 \\
\hline $45-50$ & 1.5 & 1.2 & 8 & 1.7 & 0.3 & 10 \\
\hline$>50$ & 1.3 & 0.9 & 12 & - & - & - \\
\hline
\end{tabular}

\section{Spatial differences in growth rate}

Table 4 presents estimates of annual length increments for different areas in the North Sea as obtained from tagging experiments carried out in the period 1905-11 (Borley 1916). The growth rates are similar to the results of tagging studies carried out between 1920 and 1940 (Carruthers 1924, Hickling 1938). These data provide interesting information on differences in growth rate between various parts of the southern North Sea. On the main nursery grounds, represented by Southern Bight East (area SB), the growth rate appears to be poor, while on the Doggerbank growth rates are much higher. The fish recaptured on the Doggerbank and adjacent areas were transplanted from the coastal nursery grounds along the Dutch coast and in the German Bight to the Doggerbank and there- fore do not reflect their 'natural' growth rate. Because the females used in our back-calculation study will have largely originated from the nursery areas in the Wadden Sea and adjacent shallow coastal waters (Hickling 1938), the back-calculated growth rate should be compared to the growth rate observed on the nursery grounds in the Southern Bight East.

The back-calculated growth of 4.5 to $5.6 \mathrm{~cm}$ in size classes 20-24 and 25-29 cm (Table 2) corresponds reasonably well with the estimated growth of 3.9 to $4.6 \mathrm{~cm}$ from the tagging experiments (Table 4). This correspondence again indicates that the changes in back-calculated growth reflect real changes in growth rate, despite the sources of bias discussed above.

The high growth rate of the Dogger recaptures in Table 4 , serves as an indication of the growth potential of plaice. Maximum growth at unlimited food will be
A. Year class 1963

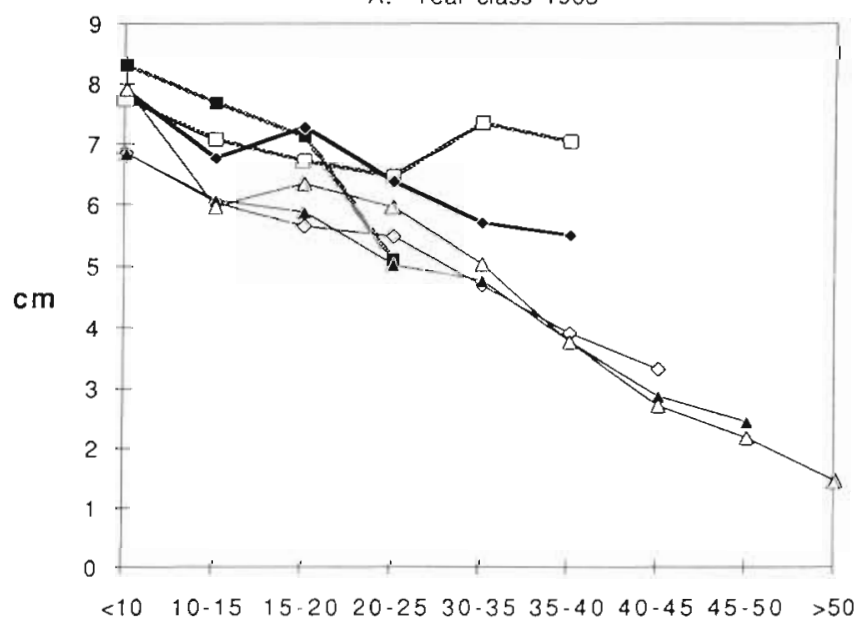

B. Year class 1969

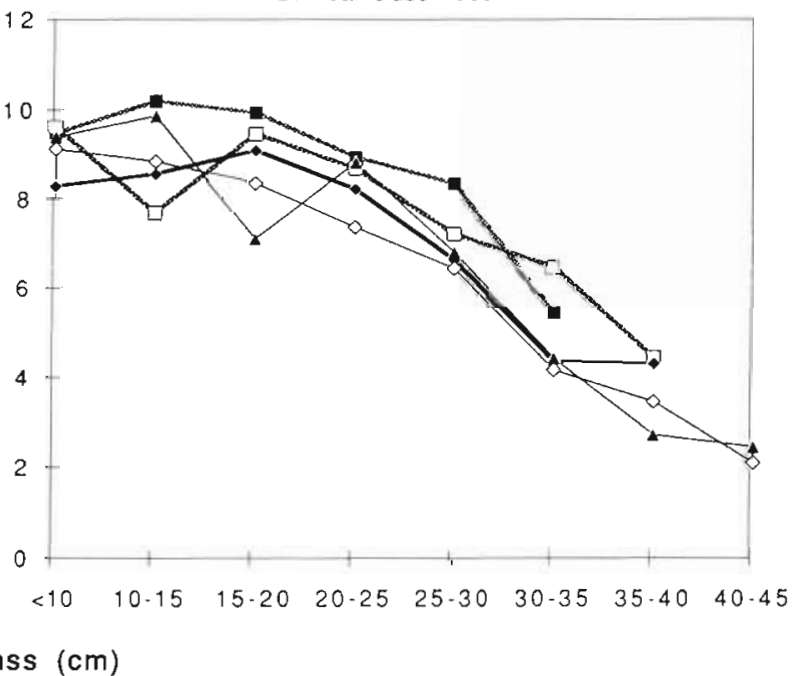

Fig. 8. Pleuronectes platessa. Back-calculated annual length increments in relation with the size for different sampling ages for

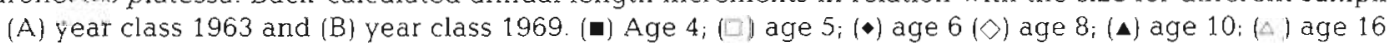


Table 4. Pleuronectes platessa. Annual length increments between 1905 and 1911 of tagged plaice in the North Sea. The length increment was calculated as the difference between the length at liberation and recapture 11 to 13 mo later for various time periods, size classes and areas. The recaptures made on the Doggerbank refer to plaice transplanted from the crowded nursery grounds in the German Bight and along the Dutch coast to the Doggerbank (Borley 1916)

\begin{tabular}{|llcr|}
\hline $\begin{array}{l}\text { Size class } \\
(\mathrm{cm})\end{array}$ & A.rea & $\begin{array}{c}\text { Annual growth } \\
\text { increment }(\mathrm{cm})\end{array}$ & $\mathrm{n}$ \\
\hline $15-19$ & & 13.3 & 33 \\
& Doggerbank & 4.4 & 8 \\
& Southern Bight East & 13.6 & 75 \\
& Doggerbank & 7.3 & 5 \\
& West of Dogger & 5.8 & 4 \\
& East of Dogger & 3.9 & 33 \\
& Southern Bight East & 12.3 & 17 \\
& Doggerbank & 6.5 & 4 \\
& West of Dogger & 7.7 & 4 \\
& East of Dogger & 5.3 & 5 \\
& Off Wash & 6.5 & 10 \\
& Southern Bight West & 4.6 & 15 \\
\hline & Southern Bight East & 4.6 & \\
\hline
\end{tabular}

dependent on temperature conditions. Fonds et al. (1992) observed in tank experiments that at unlimited food the maximum growth rate of $20 \mathrm{~cm}$ plaice increased with temperature from about $0.2 \mathrm{~mm} \mathrm{~d}^{-1}$ at $6{ }^{\circ} \mathrm{C}$ to $0.7 \mathrm{~mm}$ $\mathrm{d}^{-1}$ at $14^{\circ} \mathrm{C}$, reached a peak of $0.75 \mathrm{~mm} \mathrm{~d}^{-1}$ at $18^{\circ} \mathrm{C}$ and decreased to $0.35 \mathrm{~mm} \mathrm{~d}^{-1}$ at $22^{\circ} \mathrm{C}$. Given these growth rates and the annual temperature cycle (Fig. 9), we can calculate the expected cumulative length increments for both the coastal nursery area Southern Bight east (SB pred) and the Doggerbank (Dogger pred). Fig. 10 shows that the expected growth increment at unlimited food is

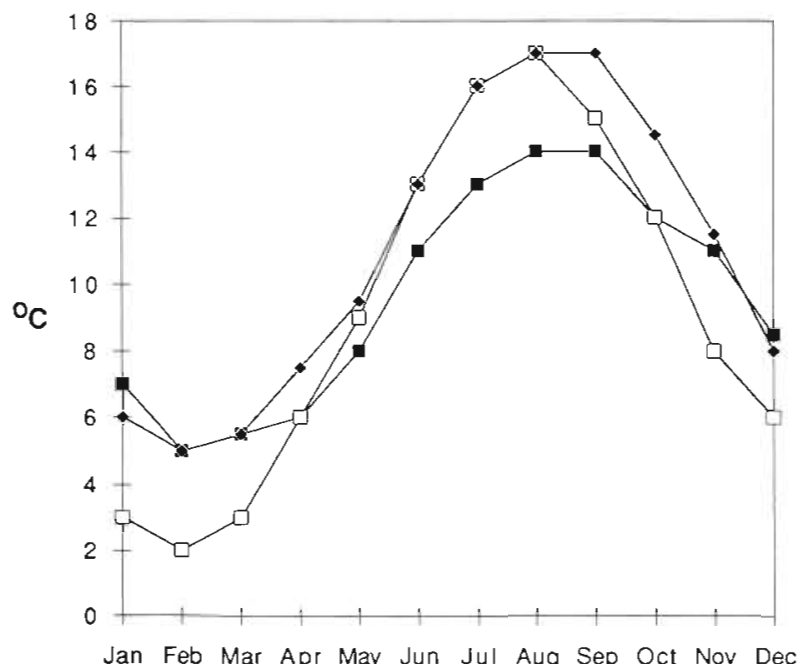

Fig. 9. Annual cycle in water temperature at the bottom in the coastal nursery areas along $(\bullet)$ the Dutch coast, $(\square)$ in the German Bight (east Frisian and Danish coast) and ( $\square$ ) on the Doggerbank (Tomzak \& Goedecke 1964)

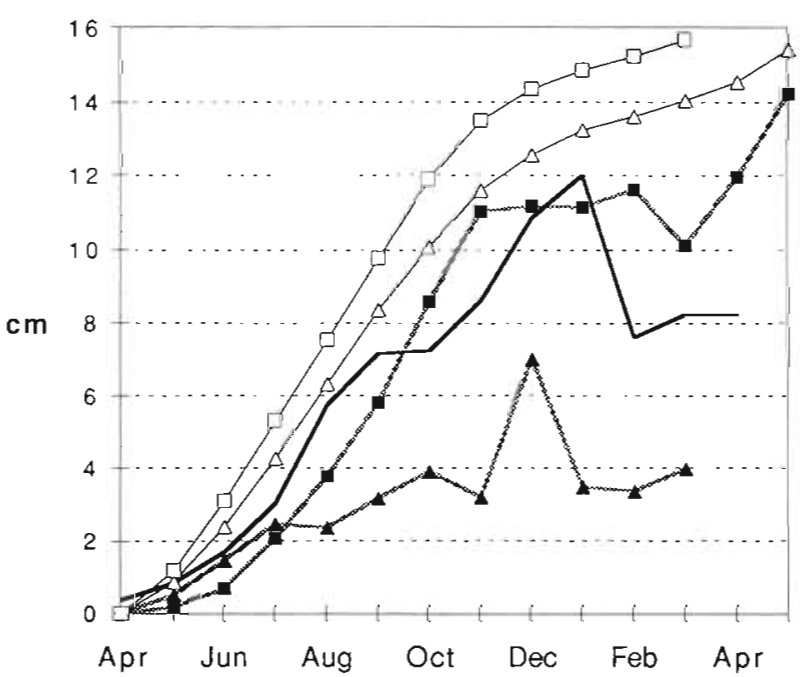

Fig. 10. Pleuronectes platessa. Cumulative length increments of $20-25 \mathrm{~cm}$ of plaice tagged and released in March-April on the nursery grounds [(4) SB 1910; (-) SB 1970] and those transplanted to the Doggerbank [( $\mathbf{(})$ Dogger 1910] compared with the predicted growth rates with unrestricted food and the average bottom temperature shown in Fig. 9 according to Fonds et al. (1992) for the Doggerbank [( $\Delta)$ Dogger pred] and the coastal nursery ground $[(\square)$ SB pred]

somewhat higher on the coastal nursery grounds than on the Dogger due to the higher water temperatures in the coastal shallows in summer. In autumn when water cools down, the growth rate decreases but remains substantial throughout the winter. This may not be realistic, since food intake decreases in autumn and almost stops in winter (Todd 1914, Rijnsdorp 1989, Fonds et al. 1992).

Fig. 10 also provides the observed cumulative length increments on the coastal nursery ground and Doggerbank as observed in historic (Borley 1916) and recent tagging experiments. In the historic experiment, which is similar to the one given in Table 4, plaice were released in March-April 1905-11 on the nursery grounds in the eastern Southern Bight (SB 1910) and in the region of the Doggerbank (Dogger 1910). In the recent experiment plaice were tagged and released in the western Wadden Sea in March 1970-75 of which 156 were recaptured within 14 mo after release (SB 1970).

The cumulative length increment in 1910 gradually increased during the year to reach a maximum in the period between October and March of about $4 \mathrm{~cm}$ in fish recaptured close to the coastal nursery area, and a maximum of about $11 \mathrm{~cm}$ in the transplanted plaice. In the early 1970s the cumulative growth shows a similar seasonal pattern with a maximum level of about $8 \mathrm{~cm}$. The high values in December and January are based on only 2 observations and are considered atypical.

Comparison of the observed and predicted growth from observed temperatures and unlimited food shows that on the coastal nursery grounds growth is well 
below the expected level in both 1910 and 1970. The slopes of the observed growth curve in 1910 is less steep than expected throughout the year, but in 1970 the slope is less steep in spring and autumn but similar between July and September. A smaller slope suggests that growth is restricted by food. On the coastal nursery grounds in 1910, growth thus seems to be restricted by food throughout the year whereas in 1970 growth seems to be restricted in spring and autumn but not in summer. The observed growth of plaice transplanted to the Dogger is only slightly below the predicted maximum possible growth in those temperature conditions. In April and May, just following tagging, the growth increments still lags behind the expected growth, but between June and November the observed growth curve run almost parallel to the expected one, suggesting that growth on the Dogger is not restricted by food. The observation that in the first month after release growth rate is smaller than expected in all tagging experiments may be artificial due to tagging.

Analysis of the monthly growth increments of the recaptures stored in the files of several of the fisheries laboratories may be used to study the periods during the year in which growth might be restricted by food in more detail. This should be done against the background of the circannual rhythm in appetite and the possible effects of tagging. Further, it should be realised that differences between the observed and expected growth rate may be due to temperature when during extremely warm summers the sea temperature exceed the temperature at which plaice show maximum growth. Fonds et al. (1992) showed that this upper temperature decreased with fish size, from $22^{\circ} \mathrm{C}$ in $5 \mathrm{~cm}$ plaice to $18^{\circ} \mathrm{C}$ in $25 \mathrm{~cm}$ plaice. This temperature effect is most likely to occur in shallow coastal areas but is likely to be restricted in time.

\section{Density-dependent growth}

Variations in plaice abundance. Variations in the abundance of juvenile plaice is indicated by data of Bannister (1978) and Rijnsdorp et al. (1991) derived from cohort analysis which are reproduced in Table 5. The data indicate that the number of plaice recruiting to the fisheries has increased substantially since the second world war. However, the year class strength estimates should be treated with caution for 2 reasons. Firstly, the cohort analysis did not take account for variations in the catch of undersized plaice (discards) which may substantially affect the number recruiting to the fisheries (van Beek et al. 1990). Secondly, there appears to be a discrepancy in the estimate of the prewar fishing mortality by Bannister (1978) and by
Table 5. Pleuronectes plaressa. Estimates of the number of 2 yr old plaice (in millions) recruiting to the fisheries as obtained by cohort analysis. The original data from Rijnsdorp et al. (1991) refered to 1 yr old recruits and were converted into 2 yr olds by assuming an annual total mortality of $10 \%$

\begin{tabular}{|ccc|}
\hline Period & Bannister (1978) & Rijnsdorp et al. (1991) \\
\hline $1929-38$ & 260 & - \\
$1947-49$ & 466 & - \\
$1950-54$ & 268 & - \\
$1955-59$ & 307 & - \\
$1960-64$ & 409 & 460 \\
$1965-69$ & 473 & 282 \\
$1970-74$ & - & 330 \\
$1975-79$ & - & 417 \\
$1980-85$ & - & 578 \\
\hline
\end{tabular}

Beverton \& Holt (1957) and Gulland (1968). Nevertheless, the conclusion seems justified that recruitment has increased considerably since the 1950s.

Variations in the abundance of adult plaice are illustrated by the catch per unit of fishing effort (CPUE) of English first class steam trawlers (Fig. 11). Before the war the CPUE varied around a low level. During the war fishing was substantially reduced in the southern North Sea and the CPUE increased by a factor of 4 to 5 in 1946. When the fisheries were resumed in 1946 the CPUE fell quickly to a low in 1950 which was slightly above the pre-war level Although the CPUE is not corrected for trends in the fishing power of the vessels (Simpson 1959) and may give an overestimate due to differences in the pattern of fish distribution (Gulland 1964), it is generally accepted that the immediate post-war increase in CPUE reflect the increase in the plaice stock by a factor of 3 (Baerends 1947, Jenssen 1947, Margetts \& Holt 1947, Beverton \& Holt 1957, Simpson 1959). Changes in the adult plaice stock since 1958 are given by Rijnsdorp et al. (1991) who showed that the spawning stock biomass increased from about $300000 \mathrm{t}$ in 1958 to a peak of $500000 t$ in 1967 and decreased to a level of $300000 t$ between 1974 and 1982.

Density-dependent growth can only occur through competition between fish sharing the same food and space. The variations in plaice abundance presented above, therefore, may not reflect variations in competitive biomass since they did not consider the distributional aspects. The CPUE on the spawning grounds does not necessarily reflect quantitatively the density on the feeding grounds. Also variations in spawning stock biomass do not necessarily reflects variations in density if the area of distribution changes. In plaice, the latter has actually occurred. Egg surveys have shown that the egg production increased substantially in the German Bight between the 1930s and 1955 (Bückmann 1961, Harding et al. 1978), in the eastern 


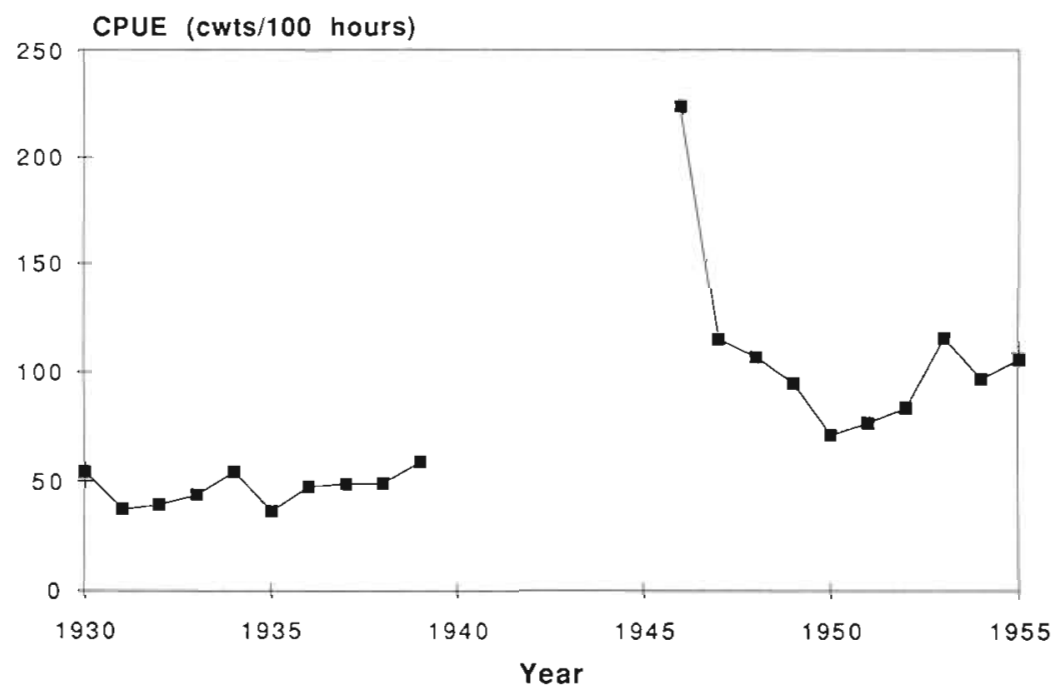

Fig. 11. Time series of the catch per unit of fishing effort (cwt per $100 \mathrm{~h}$ fishing) of 1st class steam trawlers in the Southern Bight in January and February (from Simpson 1959)

English Channel and the Flamborough area between 1948 and the 1970s (Heessen \& Rijnsdorp 1989). The increase in adult biomass indicated by trends in CPUE and SSB biomass may therefore overestimate the actual increase in competitive biomass

In a first attempt to tackle the effect of spatial overlap, Rijnsdorp \& van Beek (1991) estimated the potential competitive biomass experienced by each age group from the spatial distribution of individual age groups and information on their number and weight. The distribution of the juvenile age groups (1 to 4) were distinct and therefore competition will be

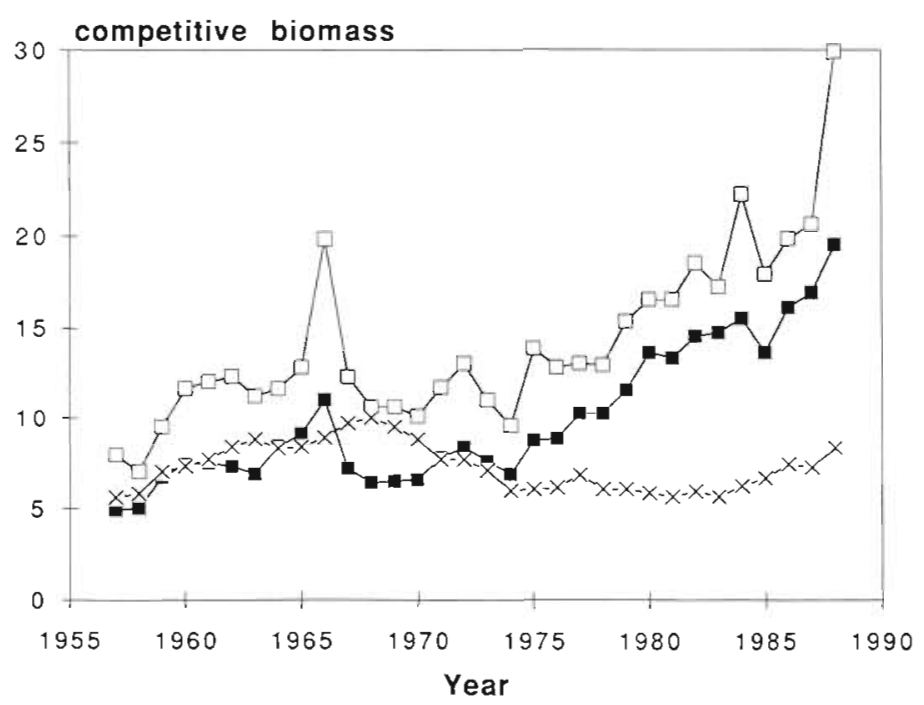

Fig. 12. Pleuronectes platessa. Time series estimates of intra-specific competitive biomass for juvenile age groups $1(\square)$ and $3(\square)$, and adult age groups 5 and older $(x)$. Rijnsdorp \& van Beek (1991) mainly restricted to individuals within a cohort. Adult plaice (age group 5 and older) exhibit a considerable overlap in distribution and therefore competition among adults will occur across cohorts.

Fig. 12 reproduces the time series information on the estimates of competitive biomass experienced by ages 1, 3 and 5 older plaice. A distinct feature in Fig. 12 is that the variations in the competitive biomass of ages 1 and 3 are almost identical and are driven by the variations in year class strength, as illustrated by the peak in the mid 1960s due to the very strong 1963 year class.

Density-dependent growth in juveniles. Evidence for density-dependent growth in juveniles $(<30 \mathrm{~cm})$ was already given in the comparison of the growth rates on the crowded nursery grounds and the less crowded Doggerbank area (Fig. 10) and the reduced growth rate of the 1963 year class which was about 3 times the average size (Fig. 6).

The growth acceleration of plaice $<30 \mathrm{~cm}$ in the 1960 s and 1970 s was restricted to those age groups that are mainly distributed in the southern North Sea and coincided with an increase in the competitive biomass (Fig. 12) which was due to an increase in the level of recruitment (Table 5). Variations in the temperature on the coastal nursery grounds of the Southern Bight east, given in Fig. 13 for the main growing period in the second and third quarter, does not show a clear relation with the increase in growth of juvenile size classes since 1950 . Since a similar growth acceleration was observed in the sole Solea solea (L.), which occupies the same areas, food availability must have increased (de Veen 1978, Rijnsdorp \& van Beek 1991).

The present growth rate, although much higher than in the 1930s, is still substantially lower than the potential growth rate indicated by the transplanted fish, suggesting that density-dependent growth still occurs.

Although there is evidence that the present level of recruitment is higher than in the 1930s, this does not necessarily imply that competition has increased. In a situation of a low food availability causing a reduction in growth rate, the density-dependent effects may be higher because of the accumulation of slow growing plaice belonging to several cohorts on the coastal nursery areas, as indicated by the occurrence of relatively old fish of up to $12 \mathrm{yr}$ in the otolith samples taken in 1932-33 on the coastal nursery 

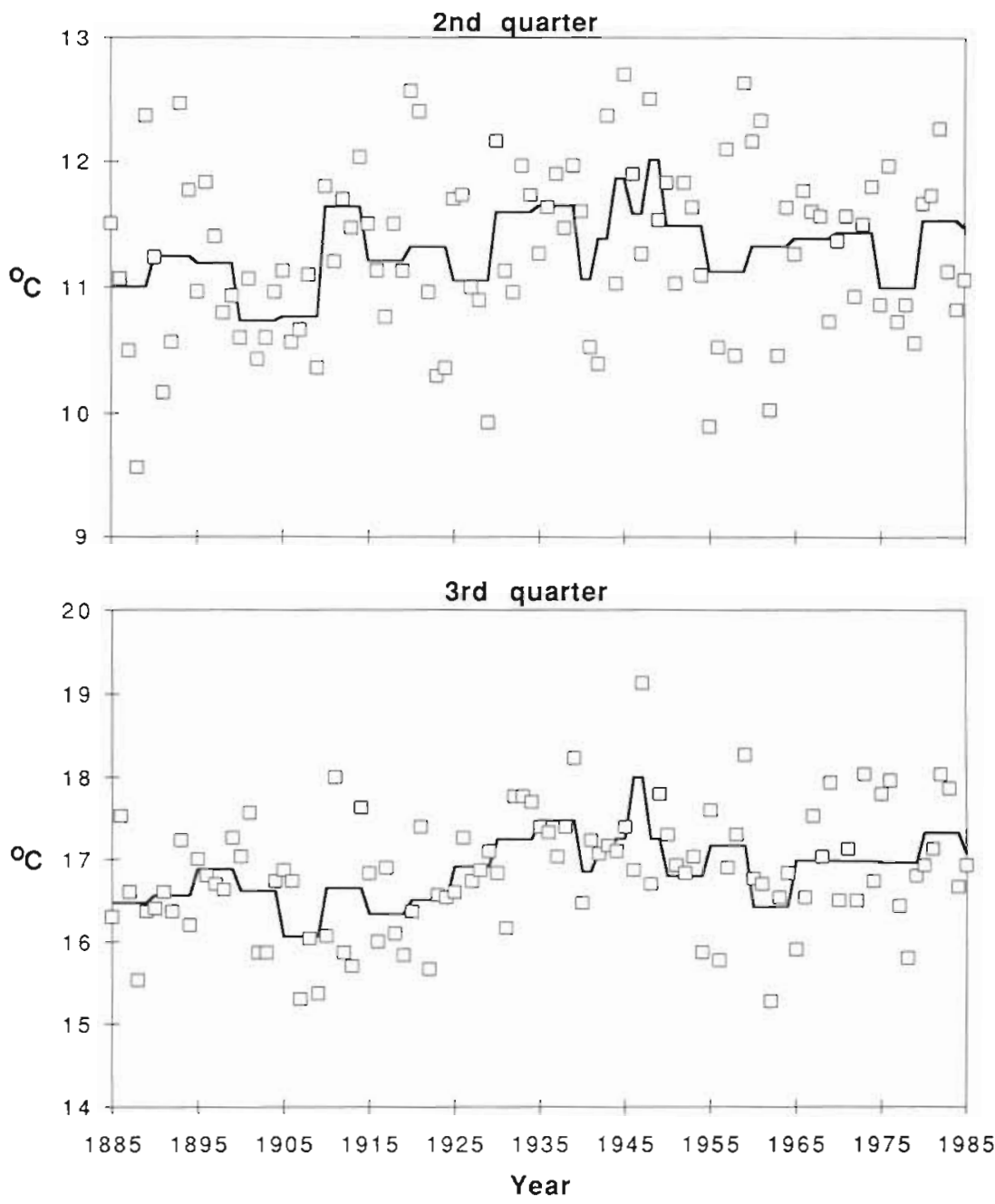

Fig. 13. Time series of the average surface water temperature on the coastal nursery ground in the Southern Bight of the North Sea in the (A) second and (B) third quarters. The thick line indicates the $5 \mathrm{yr}$ average $(2 \mathrm{yr}$ average in the period $1940-49$ )

ground (Table 1). At higher levels of food availability and consequently higher growth rates, plaice will stay in the shallow coastal nursery grounds for a shorter period, which may lead to a decrease in the density-dependent effects. From the growth curves shown in Fig. 3 we can infer that it took a plaice on average 3 to $3.5 \mathrm{yr}$ to reach $20 \mathrm{~cm}$ in the $1930 \mathrm{~s}$ and $2 \mathrm{yr}$ in the $1970 \mathrm{~s}$. In the nursery areas we will therefore find an accumulation of about 3 to 3.5 age groups in the 1930 s compared to 2 age groups in the 1970s, which roughly compensates for the lower level of recruitment.

The absence of a reduction in juvenile growth during the war period suggests that the cessation of fishing has not led to an increase in the abundance of small plaice in the coastal nurseries. However, the cessation of fishing was far from complete, especially in the coastal waters of the eastern North Sea where a limited amount of fishing was continued (Baerends 1947, Jenssen 1947).
Density-dependent growth in adults. Rijnsdorp \& van Beek (1991) were not able to identify density-dependent growth effects in adult plaice over the time period 1958-88. Over this time span adult biomass fluctuated by a factor of 2 (in Fig. 12). However, the growth depression of large plaice as observed in 1940-49 suggests that growth may also be density-dependent in the adult population.

A growth depression was first seen in medium sized plaice and later on also in the larger size groups. This might be explained by the longer time necessary to build up the competitive biomass of large plaice. However, this cannot explain why the largest growth depression occurred in 1948-49 when the CPUE had already dropped. The observation that the absolute growth depression increased with body size may be tentatively related to the relative increase in reproductive investment with body size compared to investment in somatic growth. Small fish allocate only a small proportion of their annual surplus production to reproduction and a large proportion to somatic growth, while large fish invest almost all in reproduction. A reduction in surplus production will therefore result in a relatively larger reduction in somatic growth in large fish than in small fish (Rijnsdorp \& Ibelings 1989, Rijnsdorp 1990).

No time series of sea temperatures is available for the central North Sea, the main distribution area of adult plaice during the growing period. Since this area is characterized by a stratified water column and relatively stable temperature conditions (Tomsczak \& Goedecke 1964), it is unlikely that adult plaice have experienced major changes in temperature.

Genetical changes in growth rate. The possibllity that the growth changes in small plaice reflect a change in the genetical make up of the population due to sizeselective exploitation seems unlikely since the increased growth rate was restricted to a relatively short period of about $20 \mathrm{yr}$, compared to a generation time of about $5 \mathrm{yr}$ in males and 8 yr in female plaice (Rijnsdorp in press). In addition, the transplantation experiments carried out in the early 20th century (Borley 1916) indicated potential growth rates that corresponded reasonably well to the growth rates observed in the laboratory at unrestricted food ration (Fig. 10). 
Population regulation. The evidence obtained in the present paper for density-dependent growth in juveniles and adults has some bearing on the theory on population regulation in plaice. Intensive research into the population dynamics of 0-group plaice in the western Wadden Sea has shown that growth at this stage is controlled by the ambient temperature and corresponds to the growth rate in the laboratory at unlimited food conditions (Zijlstra et al. 1982). Densitydependent mortality is restricted to a short time period directly following the settlement of post-larvae on the tidal flats (van der Veer et al. 1990). The fact that very strong year classes, such as the 1963 year class, exhibit reduced growth rates and the continuous slow growth in the 1930s, may imply increased vulnerability for predation, resulting in an increased mortality. Reanalysis of the abundance indices of 0 -and 1-group plaice in the continental nursery areas indeed showed a density-dependent mortality component (Beverton \& Iles 1992). The substantial reduction in somatic growth of adult plaice during the war implies an indirect effect on the number of eggs produced. Fecundity estimates carried out in the spawning seasons of 1948 and 1949 , the period of the largest growth depression (Fig. 5), showed a substantial reduction in the size-specific fecundity. However, the size-specific ovary weight was only marginally reduced suggesting a densitydependent trade-off between egg numbers and eggsize (Rijnsdorp 1991).

Acknowledgements. The analysis of the pre-war growth rates would not have been possible without the support of Drs R.S. Millner and J. D. Riley (Fisheries Laboratory Lowestoft, UK), who supplied the otolith material from the late 1940 s and early 1950 s. Dr M. Fonds provided data on laboratory growth of plaice. The paper improved considerably from the critical comments of Dr N. Daan and an anonymous referee.

\section{LITERATURE CITED}

Bannister, R. C. A. (1978). Changes in plaice stocks and plaice fisheries in the North Sea. Rapp. P.-v. Réun. Cons. int. Explor. Mer 172: 86-101

Baerends, G. P. (1947). A survey of the Dutch fishery for demersal seafish in the years 1939-1945. Annls. Biol. 2: $60-67$

Beverton, R. J.H. (1964). Differential catchability of male and female plaice in the North Sea and its effect on estimates of stock abundance. Rapp. P.-v. Réun. Cons. int. Explor Mer 155: 103-112

Beverton, R. J. H., Holt, S. J. (1957). On the dynamics of exploited fish populations. Fishery Invest., Ser. 2, 19

Beverton, R. J. H., Iles, T. C. (1992). Mortality rates of 0-group plaice (Pleuronectes platessa L), dab (Limanda limanda L.) and turbot (Scophthalmus maximus L.) in European waters. III. Density-dependence of mortality rates of 0 -group plaice and some demographic implications. Neth. J. Sea Res. 29: 61-79
Borley, J. O. (1916). An analysis and review of the English plaice marking experiments in the North Sea. Fishery Invest., Ser. 2, 3(3)

Borley, J. O. (1923). The plaice fishery and the war. Fishery Invest., Ser. 2, 5(3)

Bückmann, A. (1944). Die Schollenbevölkerung der Helgoländer Bucht und die Einschränkung der Fischerei während der Kriegsjahre 1914- 1918 und 1939-1942. Rapp. P.-v. Réun. Cons. int. Explor. Mer 114: 1-114

Bückmann, A. (1961). Über die Bedeutung des Schollenlaiches in der südöstlichen Nordsee. Kurze Mittl. Inst. FischBiol. Univ. Hamburg 11. 1-40

Carruthers, J N. (1924). Report on the English post-war plaice marking and transplantation experiments. Fishery Invest., Ser. 2, 6(5)

Casselman, J. M. (1987). Determination of age and growth. In: Weatherley A. H., Gill, H. S. (eds.) The biology of fish growth. Academic Press, London, p. 209-242

de Veen, J. F. (1964). On the merits of sampling spawning fish for estimating the relative abundance of different year classes in plaice. Rapp. P.-v. Réun. Cons. int. Explor. Mer 155: $94-98$

de Veen, J. F. (1978). Changes in North Sea sole stocks (Solea solea (L.)). Rapp. P.-v. Réun. Cons. int. Explor. Mer 172: $124-136$

Fonds, M., Cronie, R., Vethaak, A. D., van der Puyl, P. (1992). Metabolism, food consumption and growth of plaice (Pleuronectes platessa) and flounder (Platichthys flesus) in relation to fish size and temperature. Neth. J. Sea Res. 29: $127-143$

Francis, R. I. C. C. (1990). Back-calculation of fish length: a critical review. J. Fish Biol. 36: 883-902

Gulland, J. A. (1964). The reliability of the catch per unit effort as a measure of abundance in the North Sea trawl fisheries. Rapp. P.-v. Réun. Cons. int. Explor. Mer 155 99-102

Gulland, J. A. (1968). Recent changes in the North Sea plaice fishery. J. Cons. int. Explor. Mer 31: 305-322

Harding, D., Nichols, J. H., Tungate, D. S. (1978). The spawning of the plaice (Pleuronectes platessa L.) in the southern North Sea and English Channel. Rapp. P.-v. Réun. Cons. int. Explor. Mer 172: 102-113

Heessen, H. J. L., Rijnsdorp, A. D. (1989). Investigations on egg production and mortality of cod (Gadus morhua L.) and plaice (Pleuronectes platessa L.) in the southern and eastern North Sea in 1987 and 1988. Rapp. P.-v. Réun. Cons. int. Explor. Mer 191: 15-20

Heincke, F. (1908). Bericht über die Untersuchungen der Biologischen Anstalt auf Helgoland zur Naturgeschichte der Nutzfische. In: Herwig, W. S. (ed.) IV/V. Bericht über die Beteiligung Deutschlands an der Internationalen Meeresforschung in den Jahren 1905/6-1906/7 Verlag von Otto Salle, Berlin, p. 67-156

Hickling, C. F. (1937). The English plaice marking experiments 1929-1932. Fishery Invest., Ser. 2, 16(1)

Jenssen, A. J. C. (1947). The stocks of plaice in the North Sea and the Transition area during the war. Rapp. P.-v. Réun. Cons. int. Explor. Mer 122: 19-25

Margetts, A. R., Holt, S. J. (1947). The effect of the 1939-1945 war on the English North Sea trawl fisheries. Rapp. P.-v. Réun. Cons. int. Explor. Mer 122: 26-46

Nelson, K, Soulé, M. (1987). Genetical conservation of exploited fishes. In: Ryman, N., Utter, F. (eds.) Population genetics and fishery management. Washington Sea Grant Program. Univ. of Washington Press, Seattle, p. 345-368

Ricker, W. E. (1969). Effects of size-selective mortality and sampling bias on estimates of growth, mortality, produc- 
tion and yield. J. Fish. Res. Bd Can. 26: 479-541

Ricker, W. E. (1981). Changes in the average size and average age of Pacific salmon. Can. J. Fish. Aquat. Sci. 38 $1636-656$

Rijnsdorp, A. D. (1989). Maturation of male and female North Sea plaice (Pleuronectes platessa L.). J. Cons. int. Explor Mer. 46: 35-51

Rijnsdorp, A. D. (1990). The mechanism of energy allocation over reproduction and somatic growth in North Sea plaice Pleuronectes platessa L. Neth. J. Sea Res. 25: 279-290

Rijnsdorp, A. D. (1991). Changes in fecundity of female North Sea plaice (Pleuronectes platessa.L.) between three periods since 1900. ICES J. mar. Sci. 48: 253-280

Rijnsdorp, A. D. (in press). Selection differentials and changes in maturation and fecundity in North Sea plaice. In: Law R., Stokes, T. K. A., McGlade, J. (eds.) The exploitation of evolving populations. Springer Verlag

Rijnsdorp, A. D., Ibelings, B. (1989). Sexual dimorphism in the energetics of reproduction and growth of North Sea plaice, (Pleuronectes platessa L.). J. Fish Biol. 35: 401-415

Rijnsdorp, A. D., Daan, N., van Beek, F. A., Heessen, H. J. L. (1991). Reproductive variability in North Sea cod, plaice and sole. J. Cons int. Explor. Mer 47: 352-375

Rijnsdorp, A. D., van Beek, F. A. (1991). Changes in growth of North Sea plaice (Pleuronectes platessa L.) and sole (Solea solea L.). Neth. J. Sea Res. 27: 441-457

Rijnsdorp, A. D., van Leeuwen, P. I., Visser, T A. M. (1990). On the validity and precision of back-calculation of growth from otoliths of the plaice (Pleuronectes platessa L.). Fish. Res. 9: 97-117

Simpson, A. C. (1959). The spawning of the plaice (Pleuronectes platessa L.). Fishery Invest., Ser. 2, 22(7)

Southward, G. M. (1962). A method of calculating body

This article was presented by D. H. Cushing, Lowestoft. United Kingdom length from otolith measurements for Pacific halibut and its application to Portlock-Albatross Grounds. Data between 1935 and 1957 J. Fish. Res. Bd Can. 19: 339-362

Todd, R. A. (1914). Report on the food of the plaice. Fishery Invest, Ser. 2, 2(3)

Tomczak, G., Goedecke, E. (1964). Die thermische Schichtung der Nordsee auf Grund des mittleren Jahresganges der Temperatur in $1 / 2$ und $1^{\circ}$ Feldern. Dt hydrogr. $Z$. (Ergänzungsheft Reihe B) 4(8)

van Beek, F. A., van Leeuwen, P. I., Rijnsdorp, A. D. (1990). On the survival of plaice and sole discards in the ottertrawl and beam-trawl fisheries in the North Sea. Neth. J. Sea Res. 26: 151-160

van der Veer, H. W., Pihl, L., Bergman, M. J. N. (1990). Recruitment mechanisms in North Sea plaice, Pleuronectes platessa L. Mar. Ecol. Prog. Ser. 64: 1-12

van Leeuwen, P. I., Groeneveld, K. (1988). Leeftijdsvergelijking voor schol en tong. Internal Report ZE-88-07. Netherlands Institute for Fisheries Research, IJmuiden

Wallace, W. (1907). Report on the age and growth-rate of plaice in the southern North Sea as determined by the investigation of otoliths. Report 2, part 1. International Investigations, Marine Biological Association, London

Wallace, W. (1914). Report on age and growth and sexual maturity of the plaice in certain parts of the North Sea. Fishery Invest., Ser. 2, 2(2)

Weatherley, A. H., Gill, H. S. (1987). The biology of fish growth. Academic Press, London

Wimpenny, R. S. (1953). The plaice. Arnold, London

Zijlstra, J. J., Dapper, R., Witte, J. IJ. (1982). Settlement, growth and mortality of post-larval plaice (Pleuronectes platessa L.) in the western Wadden Sea. Neth. J. Sea Res. 15: $250-272$

Manuscript first received: April 28,1992

Revised version accepted: September 21, 1992 